\title{
ENVIRONMENTAL IMPACTS OF SPRAWLED RESIDENTIAL SETTLEMENTS: TRANSPORT DISECONOMIES IN SÃO PAULO
}

\author{
P. MORAES ${ }^{1} \&$ S. ZIONI ${ }^{2}$ \\ ${ }^{1}$ PLANMOB Engineering, Brazil \\ ${ }^{2}$ Postgraduate Program of Territorial Planning and Management, Federal University of ABC, Brazil
}

\begin{abstract}
This research addresses the issue of sustainability of high-income monofunctional urban structures sprawled within the city, considering as case study Alphaville Barueri residential condominiums in the metropolitan area of São Paulo. The aim was to investigate how these spatial structures are truly sustainable by checking their environmental efficiency according to their mobility behavioural pattern. The methodology used was to calculate the estimated transportation diseconomies produced by these sprawled urban structures through their quantification and establishment of monetary value to three indexes of environmental costs - fuel consumption, air emissions and time in congestion - and then to compare the results of the study case (the Alphaville Barueri residential condominiums) with the results of three control areas (the districts of Morumbi, Alto de Pinheiros and Pacaembu), which have been defined according to their similarity of urban design and socio-economic profile, but with different location taking into consideration the centre of the metropolis. The results pointed out that the Alphaville Barueri residential condominiums are not environmentally efficient in accordance with the defined criteria, when compared to the results of all three control areas, even if one of these areas, Morumbi, showed to be less environmentally efficient than all areas, including the case study.

Keywords: Alphaville, condominiums, environmental efficiency, transportation diseconomies, urban sprawl
\end{abstract}

\section{INTRODUCTION}

This research emerged from the observation of the striking multiplication of real estate ventures, high standard residential condominiums, outside the urban areas of major Brazilian cities and in many others. This was widely researched by Moraes [1] in her master's dissertation and largely subsidized the development of this article.

These undertakings announce greater well-being through community life and economic, social and environmental sustainability. Their own developers define it as 'planned, selfsustaining and sustainable poles composed of complete infrastructure for a rational pattern of occupation that guarantees harmony between urbanized space and the environment' [2]. Though this have not shown to be true under the prism of traffic assessments because of their economic dependence on the central business districts (CDB) of the major city they surround and also because of their inhabitant's mobility pattern based almost thoroughly on individual transportation mode (private cars).

As a result of this remoteness from the consolidated urban centres, the sprawling of these high-income residential settlements generates environmental impacts, such as air pollution and congestion, due to the mobility pattern of its occupants.

These impacts, associated with the mobility pattern of the high-income groups of the dispersed settlements, will be evaluated in this article.

From the analysis of urbanistic patterns of low environmental efficiency, this research brings to light the validity of Brazilian current urban policies for the development of cities, 
so that the formulation of new urban policies can include technical parameters for a more socially balanced and less urban fragmented city.

The purpose of this analysis was to question the aforementioned environmental efficiency (in this work understood as a set of indicators of transport diseconomies) of the residential condominiums that constitute these dispersed settlements, given their morphological and functional characteristics that imply in the intensification of commuting displacements, by private cars.

The hypothesis that high-level residential settlements are not environmentally efficient was the main line that guided this investigation. The following criteria was considered: low demographic density, monofunctionality, peripheral location and confinement.

\section{METHODOLOGY}

This investigation, which is a synthesis of the master's dissertation of the author [1], was based on the study Urban Diseconomy Reduction with the Improvement of Public Transportation [3] prepared by the Institute of Applied Economic Research (IPEA) in cooperation with the Public Transportation National Association (ANTP). At the end of the 1990s, this study developed parameters for estimation of the cost of transport-related urban diseconomies in the case of some Brazilian cities.

The analysis in this article adopted only some of the equations of the desired investigation herein intended in order to estimate the costs of the negative externalities related to individual transportation, configured as the standard mobility of the residential condominiums of Alphaville.

This is largely due to the lack of studies that offer parameters applicable to the Brazilian reality and that allow the estimation of the monetary costs of urban diseconomies related to transportation, and also due to the absence of organized, updated and available planning data.

It is especially important to clarify that the employed method for the research presented in this article cannot be replicated indistinctively to other cities for two major reasons. The first one is the above-mentioned adaptations made for the Brazilian case. The second one is the great distance between socio-economic and urban contexts between the developed countries and Brazil, as Breheny [4] very clearly states in his studies when investigating the London case of effectiveness of the policies and measures created around the compact city concept.

His findings pointed out that the energy savings, coming from the energy consumption in transport, when comparing the dispersed city and the compact-city were, in his words, 'disappointingly low'. Whereas the results obtained in the dissertation [1] that subsidized this article reveal that the high-income urban dispersion in the São Paulo case has a huge financial cost considering the aspects of atmospheric emissions, fuel consumption and congestion time.

Thus, the results of the research [1] suggest that for the application of this methodology to other localities, besides the careful adaptation of the calculation parameters of the indicators studied here for the reality of each locality, and, above all, it should be considered the great economic disparity between cities in developed and developing countries, as in the case of London in England and São Paulo in Brazil, which can have a direct effect on the calculations for the evaluation of environmental efficiency (as defined in the baseline study [1]).

The methodology developed by IPEA and ANTP [3] is basically based on two stages. The first is the quantification of the diseconomies generated by transportation, and the 


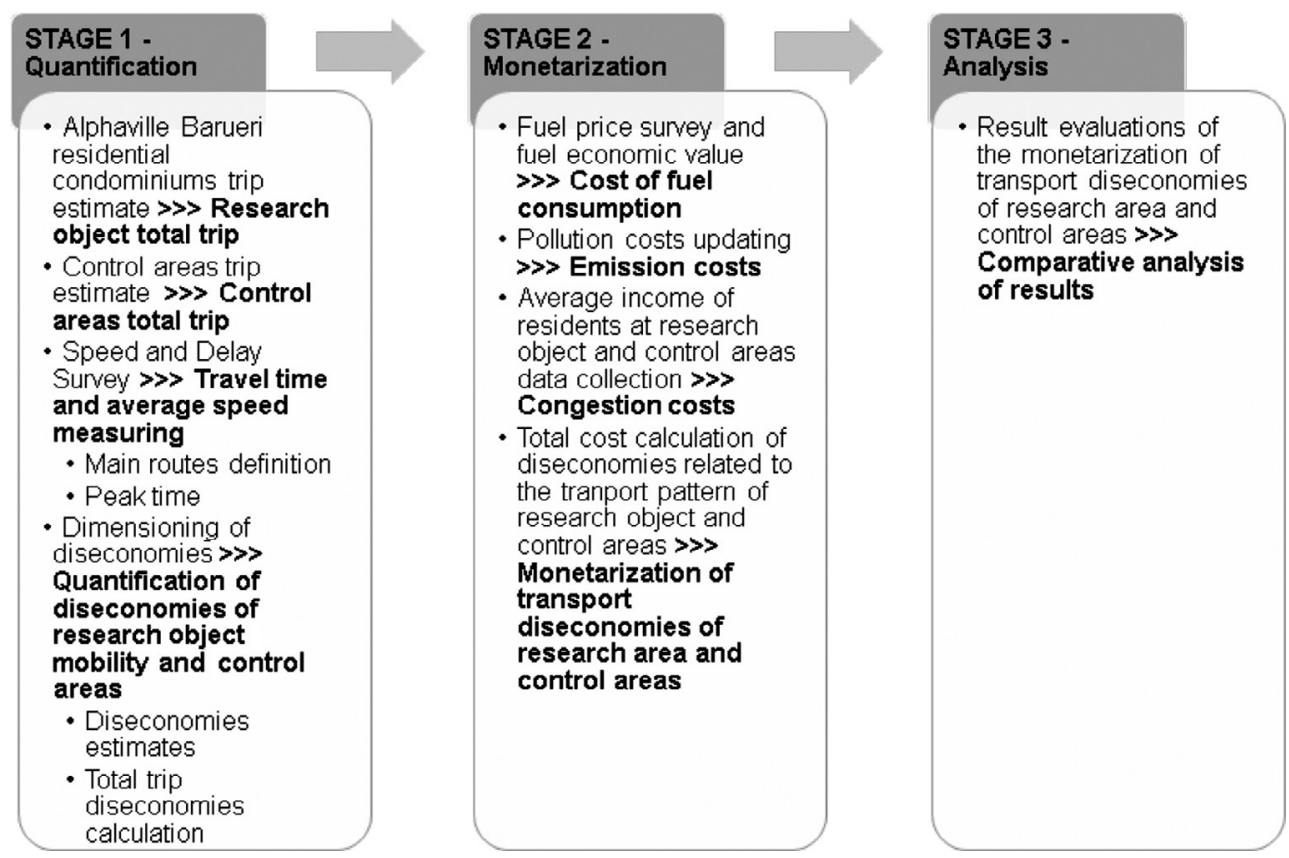

Figure 1: Synthesis of the study methodology.

second is the monetarization of these diseconomies. The aspects considered by this methodology are the time of congestion, fuel consumption and pollution (represented by atmospheric emissions from motor vehicles). Next, Fig. 1 schematically shows the employed methodology.

This research took as a case study the residential condominiums of Alphaville Barueri, in the São Paulo Metropolitan Area (SPMA), comprised by the Zone 425 of the Origin/ Destination (OD) Survey [5]. The other three districts in São Paulo city, here called control areas, were chosen to constitute a basis for comparison between these areas and the object of study. It was considered the portion of the districts contained by the OD Survey zoning, similarly to the object of study.

Additionally, the control areas met the criteria herein defined as typical of this type of settlements: low demographic density, monofunctionality, peripheral location and confinement. Moreover, the socio-economic profiles were considered, resulting in the following chosen districts: Morumbi, Alto de Pinheiros and Pacaembu (Fig. 2).

\subsection{Quantification}

\subsubsection{Estimation of generated travel by research object and control areas}

The quantification step starts with the estimation of trips carried out by the target groups of the residential condominiums of Alphaville, as well as in the control areas. The target groups are the residents of Alphaville residential condominiums, high-income individuals, as well as those of the same income class in the control areas. 


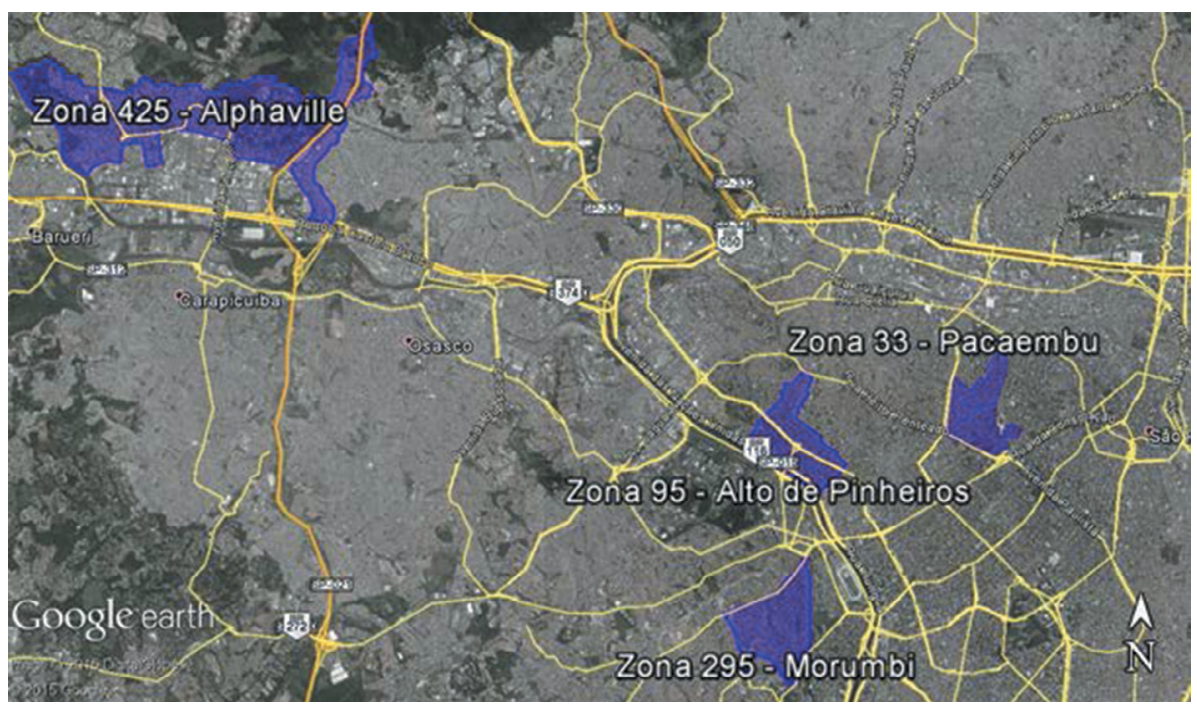

Figure 2: Alphaville Barueri (Zone 425 of the OD Survey) and control areas (corresponding OD Zones).

2.1.2 Travel time and average speed: speed and delay survey

For measuring the congestion speed and travel times, a Speed and Delay Survey was performed on typical days of August 2014 from each OD Zone studied (which covers the research object and the herein named control areas), in the peak hour of the target groups, on previously established routes, according to the main reason for travel (work), to the centre of the metropolis, even nowadays the place of greater concentration of jobs in SPMA.

\subsubsection{Quantification of the indexes of transport related diseconomies}

\subsubsection{Fuel consumption}

Fuel consumption, along with atmospheric emissions, is one of the most common indicators related to transport diseconomies, these two indicators are directly related to the speed of the vehicles [3].

The following are the equations [3] used for estimating fuel consumption, eqn (1) per route of each examined area, during morning peak hour (MPH) and the calculation of litres of consumed fuel, eqn (2).

$$
\begin{gathered}
C=0.09543+\frac{1.26643}{S}-0.00029 S \\
L=C^{*} R
\end{gathered}
$$

where:

$C=$ Consumption $(\mathrm{L} / \mathrm{km})$

$S=$ Speed $(\mathrm{km} / \mathrm{h})$

$L=$ Consumed litres per route $(\mathrm{L})$

$R=$ Route $(\mathrm{km})$ 
Table 1: Speed and delay survey results at MPH (9:00 am).

\begin{tabular}{lccc}
\hline Routes & $\begin{array}{c}\text { Route } \\
\text { distance }(\mathrm{km})\end{array}$ & $\begin{array}{c}\text { Average fuel } \\
\text { consumption }(\mathrm{L} / \mathrm{km})\end{array}$ & $\begin{array}{c}\text { Total litres } \\
\text { consumed (L) }\end{array}$ \\
\hline 1. Alphaville - SP Centre & 30.0 & 0.133 & 3.99 \\
2. Morumbi - SP Centre & 12.5 & 0.207 & 2.59 \\
3. Alto de Pinheiros - SP Centre & 10.5 & 0.154 & 1.62 \\
4. Pacaembu - SP Centre & 4.5 & 0.195 & 0.88 \\
\hline
\end{tabular}

The summary of the fuel consumption estimates and the total of litres consumed in each route analysed, considering the behaviour of the trip at the MPH of the surveyed days, are illustrated in Table 1.

\subsubsection{Atmospheric emissions}

For the adopted methodology, four equations were developed for the quantification of four elements: $\mathrm{CO}, \mathrm{HC}, \mathrm{NO}_{\mathrm{x}}$ and $\mathrm{PM}$ (particulate matter). In the case of automobiles, only three equations were developed, considering the most significant pollutants in the emissions of this group of motorized mobile sources. They are $\mathrm{CO}$ (eqn 3), $\mathrm{HC}$ (eqn 4) and $\mathrm{NO}_{\mathrm{x}}$ (eqn 5). These equations are directly related to the speed of mobile sources, like in the case of fuel consumption, but based on speeds $\leq 80 \mathrm{~km} / \mathrm{h}$.

Where:

$$
\begin{gathered}
\mathrm{HC}=-2.8+\frac{62.48}{S} \\
\mathrm{CO}=-4.51+\frac{727}{S}+1.34 \times 10^{-3} S^{2} \\
\mathrm{NO}_{x}=1.03+7.477 \times 10^{-5} S^{2}
\end{gathered}
$$

$\mathrm{HC}=$ Hydrocarbonate emissions $(\mathrm{g} / \mathrm{km})$

$\mathrm{CO}=$ Carbon monoxide emissions $(\mathrm{g} / \mathrm{km})$

$\mathrm{NO}_{\mathrm{x}}=$ Nitrogen oxide emissions $(\mathrm{g} / \mathrm{km})$

$\mathrm{S}=$ Speed $(\mathrm{km} / \mathrm{h})$

The summary of the total emissions of pollutants per route analysed, is shown in Table 2 . The emissions of Route 1: Alphaville are significantly higher than the emissions of control areas routes, except for the emission of $\mathrm{HC}$ that by a difference of $2.32 \mathrm{~g}$ was greater in Route 2: Morumbi.

Table 2: Emissions of pollutants ( $\mathrm{HC}, \mathrm{CO}$ and $\left.\mathrm{NO}_{\mathrm{x}}\right)$ at $\mathrm{MPH}(9: 00 \mathrm{am})$.

\begin{tabular}{lccc}
\hline Routes & $\begin{array}{c}\text { HC emitted } \\
(\mathrm{g})\end{array}$ & $\begin{array}{c}\mathrm{CO} \text { emitted } \\
(\mathrm{g})\end{array}$ & $\begin{array}{c}\mathrm{NO}_{\mathrm{x}} \text { emitted } \\
(\mathrm{g})\end{array}$ \\
\hline 1. Alphaville - SP Centre & 66.37 & 839.57 & 36.75 \\
2. Morumbi - SP Centre & 68.69 & 792.20 & 13.35 \\
3. Alto de Pinheiros - SP Centre & 31.43 & 363.79 & 11.44 \\
4. Pacaembu - SP Centre & 22.09 & 254.37 & 4.80 \\
\hline
\end{tabular}




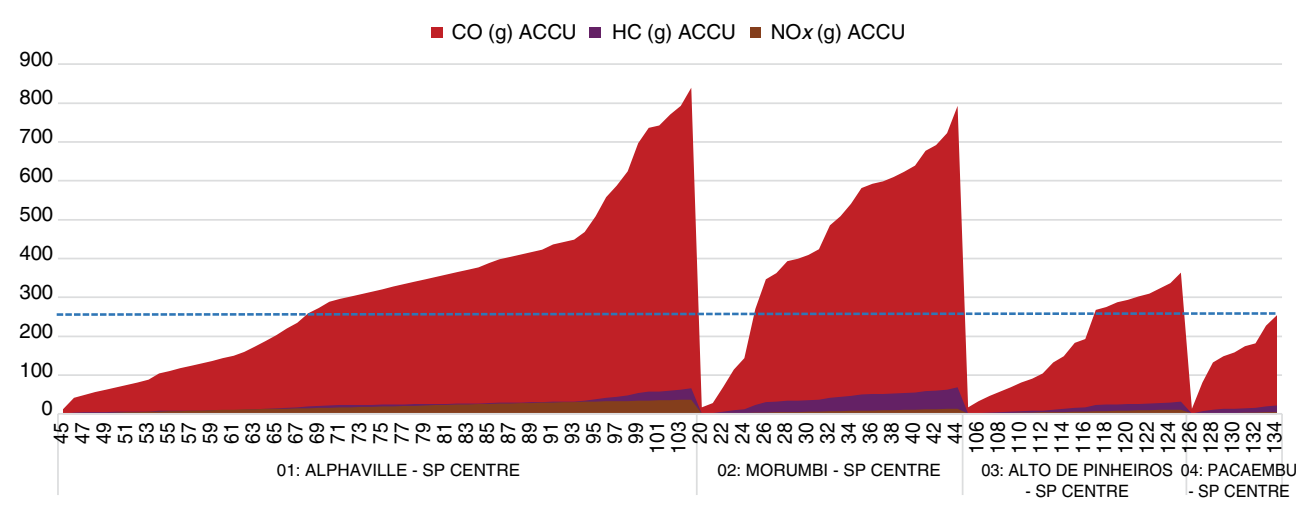

Figure 3: Accumulated emissions ( $\mathrm{HC}, \mathrm{CO}$ and $\left.\mathrm{NO}_{\mathrm{x}}\right)$ by route at $\mathrm{MPH}(9: 00 \mathrm{am})$.

By comparing the total amount of emissions of each pollutant along each route, it is possible to infer that the distance travelled has a crucial influence in determining the total pollutants emitted along each route (Fig. 3).

It can be inferred that in addition to the low speeds, the length of the routes travelled by motorized mobile sources are also determinant in the final amount of pollutant emissions. Figure 3 above shows the cumulative emissions totals per searched route.

\subsubsection{Time in congestion}

The quantification of the time in congestion does not require an estimation equation, but simply the direct measurement by the carried-out Speed and Delay Survey, that also measured the average speed performed by the vehicle used and the total time in which the vehicle stopped but remained in operation. The results obtained are shown in Table 3, which shows the timing measured in each route.

Observing the data obtained for the time in congestion, it can be noticed that the stopped time of the research object is not the longest one, despite its total travel time being the longest. Morumbi District accumulated the longest time in congestion (stopped time). It is more than twice the time obtained in Route 1, even if its total travel time is almost the same of Route 1.

This situation can alter the perception of the users of individual transport that despite having to go through a longer and slower route, may feel it is worth it due to the relativization of the spent time in traffic.

Table 3: Congestion time at MPH (9:00 am).

\begin{tabular}{lccc}
\hline & \multicolumn{3}{c}{ Timing } \\
\cline { 2 - 4 } Routes & Total travel time & Time in motion & Stopped time \\
\hline 1. Alphaville - SP Centre & $1: 14: 24$ & $1: 02: 52$ & $0: 11: 32$ \\
2. Morumbi - SP Centre & $1: 09: 24$ & $0: 44: 12$ & $0: 25: 12$ \\
3. Alto de Pinheiros - SP Centre & $0: 34: 18$ & $0: 26: 08$ & $0: 08: 10$ \\
4. Pacaembu - SP Centre & $0: 24: 31$ & $0: 15: 20$ & $0: 09: 11$ \\
\hline
\end{tabular}




\subsection{Monetarization}

The second stage of the methodology, the monetarization of transport diseconomies, starts from the amounts obtained in the previous stage and calculates the monetary value of these diseconomies, based on the values formulated by IPEA and ANTP [3]. However, at this stage, a correction of the values indicated by the study was performed, given that this study was elaborated in 1998. Table 4 shows the monetary values for each element used in the monetization calculations of transport diseconomies defined by the IPEA and ANTP [3] study and the monetary values corrected by IPC-FIPE Brazilian index. Thus, it is believed to have greater comparative equity and a more realistic approximation of the valuation of measured transport diseconomies.

\subsubsection{Cost of fuel consumption}

For the total consumption of litres estimated for each route, the cost of this consumption was calculated based on the economic price of gasoline in São Paulo, Brazil, in January 2015, and then this operation was repeated for the volume of trips at peak time for the research object and the control areas, as shown in Table 5.

Thus, it is concluded that the cost of fuel consumption, in this case gasoline, for journeys performed by residential unit in the morning peak hour by the Alphaville Barueri residences are significantly higher than the estimated costs for the neighbourhoods of the control areas. The cost of consumption for the volume of trips in MPH alone is a good indicator of the diseconomy generated by dispersed occupations such as the Alphaville Barueri residences.

Table 4: Monetary correction of estimated values of transportation diseconomies.

\begin{tabular}{lll}
\hline $\begin{array}{l}\text { Elements of the } \\
\text { monetarization calculation }\end{array}$ & $\begin{array}{l}\text { Estimated value } \\
\text { IPEA/ANTP [3] }\end{array}$ & $\begin{array}{l}\text { Corrected value } \\
\text { (January 2015) }\end{array}$ \\
\hline $\begin{array}{l}\text { Economic value of fuel } \\
\text { gasoline) }\end{array}$ & $72 \%$ Pump price & $66 \%$ Pump price $(66 \% *$ \\
$\mathrm{CO}$ & $\mathrm{R} \$ 3.299 / \mathrm{L}=\mathrm{R} \$ 2.177 / \mathrm{L})$ \\
$\mathrm{HC}$ & $\mathrm{R} \$ 1.19 / \mathrm{kg}$ & $\mathrm{R} \$ 0.45 / \mathrm{kg}$ \\
$\mathrm{NO}_{\mathrm{x}}$ & $\mathrm{R} \$ 1.12 / \mathrm{kg}$ & $\mathrm{R} \$ 2.74 / \mathrm{kg}$ \\
Particles & $\mathrm{R} \$ 0.91 / \mathrm{kg}$ & $\mathrm{R} \$ 2.70 / \mathrm{kg}$ \\
\hline
\end{tabular}

Table 5: Total cost of fuel consumption for total estimated trips at MPH (9:00 am).

\begin{tabular}{lcccc}
\hline \multirow{2}{*}{ Routes } & \multicolumn{4}{c}{ Consumption, trips and cost } \\
\cline { 2 - 5 } & $\begin{array}{c}\text { Total } \\
\text { consumed } \\
\text { litres }(\mathrm{L})\end{array}$ & $\begin{array}{c}\text { Cost of } \\
\text { consumed } \\
\text { fuel by trip } \\
(\mathrm{R} \$ / \mathrm{L} / \mathrm{km})\end{array}$ & $\begin{array}{c}\text { Total } \\
\text { estimated trips } \\
\text { by residential } \\
\text { unit (trips/RU) }\end{array}$ & $\begin{array}{c}\text { Total cost of } \\
\text { consumed } \\
\text { fuel by trip } \\
\text { (R } \$ / \mathrm{L} / \text { trip) }\end{array}$ \\
\hline 1. Alphaville - SP Centre & 3.99 & $\mathrm{R} \$ 11.08$ & 2,107 & $\mathrm{R} \$ 23,346.04$ \\
2. Morumbi - SP Centre & 2.59 & $\mathrm{R} \$ 7.19$ & 2,425 & $\mathrm{R} \$ 17,441.64$ \\
3. A. Pinheiros - SP Centre & 1.62 & $\mathrm{R} \$ 4.50$ & 1,616 & $\mathrm{R} \$ 7,269.96$ \\
4. Pacaembu - SP Centre & 0.88 & $\mathrm{R} \$ 2.44$ & 2,463 & $\mathrm{R} \$ 6,018.98$ \\
\hline
\end{tabular}




\subsubsection{Cost of atmospheric emissions}

The monetarization method proposed by IPEA and ANTP [3] works with an approximation of the values defined by studies prepared for North America and Europe, which are expressed in US $\$ / \mathrm{kg}$ of emissions. Because of the lack of specific studies that determine some of the specific variables for the Brazilian case, such as dispersion, climate, terrain and health costs related to pollution, the values already estimated by the Americans and Europeans have been adapted by establishing a correlation with the per capita income in Brazil and the United States, those values have been updated in accordance with Brazilian economic indexes by the time of this research (January 2015):

$$
\begin{gathered}
\mathrm{CO}=\mathrm{R} \$ 0.45 / \mathrm{kg} \\
\mathrm{HC}=\mathrm{R} \$ 2.74 / \mathrm{kg} \\
\mathrm{NOx}=\mathrm{R} \$ 2.70 / \mathrm{kg}
\end{gathered}
$$

For the estimated atmospheric emission quantities for each route made from the analysed areas at the morning rush hour, we have the results shown in Table 6.

It is noteworthy that, unlike the estimated volumes of atmospheric emissions, Route 2: Morumbi - SP Centre exceeded the costs of Route 1: Alphaville - Barueri in relation to two pollutants: hydrocarbons and carbon monoxide. However, in terms of volume of pollutant, Morumbi had exceeded Alphaville only in terms of the amount of hydrocarbons (HC). These results indicate that the average speed performed and the distance travelled are fundamental to the emission costs of pollutants.

\subsubsection{Cost of time in congestion}

The study of IPEA and ANTP [3] established an equation for estimating the hour value, which is then used to estimate the cost of time spent in congestion, considering an average income for the whole city, to the detriment of the income of each user of public transportation by bus or individual transportation by private cars. In this study, an approximation was made, adopting the average income within the limits of the OD zone of each analysed area - object of research and control areas - but using the socioeconomic income data of the last census carried out by the IBGE [6], in 2010. Therefore, the equation used to estimate the time value, and then estimate the cost of the congestion time, used in this research was defined as follows (eqn 6):

$$
\mathrm{TV}=\frac{\mathrm{AIZOD}_{\alpha, \mathrm{m}, \mathrm{ap}, \mathrm{p}} \times \mathrm{SC} \times \mathrm{FA} \times \mathrm{HP}}{\mathrm{NH}}
$$

Table 6: Cost of pollutant emissions $\left(\mathrm{HC}, \mathrm{CO}\right.$ and $\left.\mathrm{NO}_{\mathrm{x}}\right)$ for total estimated trips at $\mathrm{MPH}$ (9:00 am).

\begin{tabular}{lccc}
\hline Routes & $\begin{array}{c}\text { Cost of HC for } \\
\text { the estimated } \\
\text { trips }(\mathrm{R} \$)\end{array}$ & $\begin{array}{c}\text { Cost of CO for } \\
\text { the estimated } \\
\text { trips }(\mathrm{R} \$)\end{array}$ & $\begin{array}{c}\text { Cost of } \mathrm{NO}_{\mathrm{x}} \text { for } \\
\text { the estimated } \\
\text { trips }(\mathrm{R} \$)\end{array}$ \\
\hline 1. Alphaville - SP Centre & $\mathrm{R} \$ 383.17$ & $\mathrm{R} \$ 796.04$ & $\mathrm{R} \$ 209.08$ \\
2. Morumbi - SP Centre & $\mathrm{R} \$ 456.41$ & $\mathrm{R} \$ 864.49$ & $\mathrm{R} \$ 87.42$ \\
3. A. Pinheiros - SP Centre & $\mathrm{R} \$ 139.17$ & $\mathrm{R} \$ 264.55$ & $\mathrm{R} \$ 49.92$ \\
4. Pacaembu - SP Centre & $\mathrm{R} \$ 149.08$ & $\mathrm{R} \$ 281.93$ & $\mathrm{R} \$ 31.92$ \\
\hline
\end{tabular}


Table 7: Time value and total congestion time at MPH (9:00 am).

\begin{tabular}{lcccr}
\hline Routes & $\begin{array}{c}\text { Time } \\
\text { value } \\
(\mathrm{R} \$ / \mathrm{h})\end{array}$ & $\begin{array}{c}\text { Time in } \\
\text { congestion } \\
\text { (stopped time) }\end{array}$ & $\begin{array}{c}\text { Total estimated } \\
\text { trips by residential } \\
\text { unit (trips/RU) }\end{array}$ & $\begin{array}{c}\text { Total cost of } \\
\text { congestion }\end{array}$ \\
\hline 1) Alphaville - SP Centre & $\mathrm{R} \$ 33.31$ & $0: 11: 32$ & 2,107 & $\mathrm{R} \$ 12,866.39$ \\
2) Morumbi - SP Centre & $\mathrm{R} \$ 22.35$ & $0: 25: 12$ & 2,425 & $\mathrm{R} \$ 22,585.91$ \\
3) A. Pinheiros - SP Centre & $\mathrm{R} \$ 24.29$ & $0: 08: 10$ & 1,616 & $\mathrm{R} \$ 5,234.19$ \\
4) Pacaembu - SP Centre & $\mathrm{R} \$ 20.05$ & $0: 09: 11$ & 2,463 & $\mathrm{R} \$ 7,406.02$ \\
\hline
\end{tabular}

where:

$\mathrm{TV}=$ Time value $(\mathrm{R} \$ / \mathrm{h})$

AIODZ $=$ Average income in OD Zone $(\mathrm{R} \$ / \mathrm{h})$, being $\alpha=$ Alphaville, $\mathrm{m}=$ Morumbi, ap $=$ Alto de Pinheiros and $\mathrm{p}=$ Pacaembu

$\mathrm{SC}=$ Social charges $95.02 \%=1.9502$

$\mathrm{FA}=0.3$ (possibility of alternative use in a useful amount of time)

$\mathrm{HP}=$ Percentage of productive use of time (\% work trip $+\%$ home trip - work $* 0.75)$.

When not available, use 0.5

$\mathrm{NH}=$ Number of working hours per month $=168 \mathrm{~h}$

By applying the value of the time found for each area of analysis to the time lost in congestion measured in each route and multiplying this result by the number of trips estimated at MPH also for each route, we obtain the total cost of the time in congestion of each route checked, as shown in Table 7.

The cost of congestion among the evaluated routes was high in Route 1: Alphaville even though Route 2: Morumbi reached a congestion cost almost twice that of Route 1 . This result indicates that the time stopped in the congestion has significant weight in the determination of this cost. Another factor that points out to be relevant is the fact that all routes, except Route 1: Alphaville, are in urban areas, counting on a road system with low road capacity, with many impedances, while Route 1 is about $80 \%$ of its route, highway road system with high road capacity, such as Castello Branco Highway and the Express Way Marginal Tietê, with very low impedances, gaining free-flow speed for longer period of time over the entire course.

\section{CONCLUSION: CHALLENGES AND PERSPECTIVES}

The results obtained show that the Alphaville Barueri residences came in second in the list of environmental inefficiency under the aspect of mobility, when compared to the Morumbi neighbourhoods, which presented the highest environmental inefficiency. It can be considered that this type of urban structure is not environmentally efficient, for this research, because the rates observed for Alphaville are very close to that of the Morumbi control area (see Table 8), especially regarding to the cost of atmospheric pollutant emissions.

Among the transport related diseconomies herein evaluated, the cost of fuel consumption showed to be the highest among the three of them, and time in congestion the second most expensive diseconomy. This outcome reflects that transport diseconomies related to more tangible issues such as fuel cost and time lost in congestion are more valued financially. 
Table 8: Classification of environmental efficiency according to the monetary values of the object of study and control areas.

\begin{tabular}{lcccc}
\hline & \multicolumn{3}{c}{ Indicators } & \\
\cline { 2 - 4 } $\begin{array}{l}\text { Areas of } \\
\text { analysis }\end{array}$ & $\begin{array}{c}\text { Cost of fuel } \\
\text { consumption } \\
(\mathrm{R} \$)\end{array}$ & $\begin{array}{c}\text { Cost of } \\
\text { atmospheric } \\
\text { emissions }(\mathrm{R} \$)\end{array}$ & $\begin{array}{c}\text { Cost of time } \\
\text { in congestion } \\
(\mathrm{R} \$)\end{array}$ & $\begin{array}{c}\text { Environmental } \\
\text { efficiency } \\
\text { classification }(\mathrm{R} \$)\end{array}$ \\
\hline Alphaville & $23,346.04$ & $1,388.29$ & $12,866.39$ & $37,600.72$ \\
Morumbi & $17,441.64$ & $1,408.32$ & $22,585.91$ & $41,435.87$ \\
A. Pinheiros & $7,269.96$ & 453.64 & $5,234.19$ & $12,957.79$ \\
Pacaembu & $6,018.98$ & 462.93 & $7,406.02$ & $13,887.93$ \\
\hline
\end{tabular}

Atmospheric emissions have shown to be less relevant transport diseconomy, perhaps because it is a diffuse and less concrete impact. Calculations for their monetarization do not include the costs of their effects on current and future human health. This can be justified because the value of life and the cost of health of every individual in poor and developing countries are not high.

These results reveal how unbalanced the technical parameters regarding the pricing of transport diseconomies are and indicate the urgency of their revision and the establishment of new methodologies for estimating the environmental impacts related to transport and tackle the challenge of incorporating this technical-scientific framework into the design of public policies so that the regulation of urban development is more equitable.

In the Brazilian case, the existence of a large gap in the technical-scientific development regarding methodologies for estimating the diseconomies related to transport must be added, either because of its complexity or because of the unavailability of updated organized planning data.

Despite the imbalance between the transport diseconomies evaluated, the variables that make up each one of the indicators adopted for the evaluation of the environmental efficiency, have shown to be fairly balanced as Table 9 illustrates.

Although with different weights in the composition of each indicator, the variable present in all indicators is the 'total distance travelled'. This variable suggests the importance of the location of urban occupation and brings out the relevance of the inclusion of the urban dispersion debate in public policies and moreover should consider being more restrictive regarding

Table 9: Analysis of the weight of the variables of each indicator.

\begin{tabular}{lcc}
\hline Indicators & Variables & Weights \\
\hline Cost of fuel & Total distance travelled & ++ \\
consumption & Average speed & + \\
Cost of atmospheric & Average speed & ++ \\
emissions & Total distance travelled & + \\
Cost of time in & Time in congestion & ++ \\
congestion & Total distance travelled & + \\
\hline
\end{tabular}


territorial occupation and urban production monitoring seeking to reduce the time lost in long daily commuting.

Although the statement of sustainable development is embedded in the rhetoric of public policies at its various scales (local, regional, national and international), in practice, urban development is still largely driven by economic growth. This statement is commonplace regarding theories of unequal and predatory development. However, for genuine change to occur, it is absolutely necessary that the social and environmental dimensions place themselves at the centre of the social structure and the economic dimension lies on the periphery of the first two as a framework of support that enables the desires expressed by that society.

\section{REFERENCES}

[1] Moraes, P.M., Impactos ambientais dos assentamentos residenciais dispersos: deseconomias de transporte em São Paulo. Master degree dissertation, presented at Postgraduate Program of Territorial Planning and Management of the Federal University of ABC, Santo André/São Paulo/Brasil, 25 May 2015.

[2] Alphaville Urbanismo S.A, Alphaville, available at: <http://www.alphaville.com.br/ portal/>, (accessed on 8 April 2014).

[3] ANTP/IPEA, Redução das Deseconomias Urbanas com a Melhoria do Transporte Público - Relatório Final, 1998.

[4] Breheny, M., The compact city and the transport energy consumption. Transactions of the Institute of British Geographers, 20(New Series), pp. 81-101, 1995. DOI: 10.2307/622726.

[5] Metrô SP, Companhia do Metropolitano de São Paulo, Pesquisa de Origem e Destino 2007: Região Metropolitana de São Paulo, available at www.metro.sp.gov.br/metro/ numeros-pesquisa/pesquisa-origem-destino-2007.aspx, (accessed on 18 October 2014).

[6] IBGE, Censo 2010 Brasil IBGE, Ministério do Planejamento, Orçamento e Gestão, available at www.censo2010.ibge.gov.br, (accessed on 21 April 2015). 